\section{Agenda-setting e framing: reafirmando os efeitos limitados}

\section{RESUMO}

Este artigo retoma a discussão a respeito dos estudos relativos ao agendamento que contestam a teoria dos efeitos limitados dos meios de comunicação.

\section{ABSTRACT \\ This article comments upon some critical studies which deny the limited effects of the mass media as held by the agenda- setting hypothesis.}

PALAVRAS-CHAVE (KEY WORDS)

- Agendamento (Agenda-setting)

- Meios de comunicação (Mass media)

- Poder (Power)
Leandro Colling ${ }^{1}$

Prof. Jornalismo da Faculdade Dois de Julho - Bahia
Introdução

O número 7 da ReVista Famecos dedicou amplo espaço para os estudos do agendasetting. Com o objetivo de colaborar com a continuidade da discussão, este artigo retoma o debate sobre a tese de que os estudos sobre o agendamento contestam a teoria dos efeitos limitados dos meios de comunicação. Basicamente, temos dois objetivos neste texto: demonstrar que não é unânime a tese de que o agendamento contesta o paradigma dos efeitos limitados, como faz crer Traquina (1995), no seu conhecido texto $\mathrm{O}$ paradigma do "agendasetting". Redescoberta do poder do jornalismo ${ }^{2}$; o outro tem uma ligação com o primeiro, mas fica centrado na defesa de que o enquadramento é o herdeiro natural do agenda-setting. A confluência desses estudos, entretanto, também gerou conclusões conflitantes sobre o poder dos enquadramentos da mídia nos receptores e do estabelecimento de temas na agenda da audiência.

O agenda-setting: efeito poderoso ou limitado?

Diversos textos já foram escritos para relatar a evolução dos estudos sobre o agenda-setting. Por isso, não faremos um relato do que já foi sistematizado por outros autores, mas apenas um breve resgate histórico para tratar sobre o contexto em que nasceram as pesquisas e de como elas se situam na teoria da comunicação.

Nos vários textos que contam a evolução dos estudos sobre o agendasetting (McCombs, 1996; Traquina, 1995; Hohlfeldt, 1997), Maxwell McCombs e 
Donald L. Shaw sempre são apontados como fundadores dessas pesquisas, inspirados por Walter Lippmann, autor do livro Public Opinion, lançado em 1922. Lippmann é citado tantas vezes porque destacou o papel desempenhado pelos meios informativos ao definirmos o nosso mundo, nos dizendo quais são os assuntos mais importantes que estão ao nosso redor. Para ele, dependemos dos meios de comunicação para nos informar sobre os assuntos, personalidades e situações; para que possamos experimentar sentimentos de apoio ou de repulsa e para conhecer aqueles pontos de atenção medidos pelas sondagens de opinião.

Lippmann já fez uma distinção importante entre o mundo que existe "realmente" e as nossas percepções privadas deste mundo. Um capítulo do seu livro é intitulado $O$ mundo exterior e as imagens em nossas cabeças. $\mathrm{O}$ autor argumentou que os meios informativos esboçam muitas destas imagens em nossas mentes (citado em McCombs, 1996, p.14). Em 1963, Bernard Cohen lança The Press and Foreign Policy e escreve que a imprensa pode, na maior parte das vezes, não conseguir dizer às pessoas como pensar, mas tem, no entanto, uma capacidade espantosa para dizer aos seus próprios leitores sobre o que pensar. "O mundo parece diferente para pessoas diferentes, dependendo do mapa que thes é desenhado pelos redatores, editores e diretores de jornal que o lêem." (citado em Traquina, 1995, p.193)

Foi em 1972 que McCombs e Shaw publicaram o primeiro artigo tentando provar o que Lippmann e Cohen já haviam escrito. A pesquisa foi realizada em 1968, na localidade de Chapell Hill, cidade pequena, conservadora e isolada que fica na Carolina do Norte, nos Estados Unidos. Nos 24 dias que antecederam as eleições nacionais, foram aplicados cem questionários, selecionados na relação de eleitores, de maneira a cobrir um universo variado de posição econômico-financeira, social e racial, dentre aqueles que se encontravam indecisos entre votar em Hubert Humprey ou Richard Nixon. Feito isso, verificouse que a mídia havia provocado um forte impacto e influenciado significativamente o eleitor. Mais do que influenciar o eleitor, a mídia também terminara por influenciar aos próprios candidatos. Muitos deles incluíram em suas agendas temas que, inicialmente, não constavam em suas preocupações. Isso ocorreu depois que os temas foram abordados por seus concorrentes e/ou pela mídia (citado em Hohlfeldt, 1997, p.45 e 46).

Depois desta primeira pesquisa, vários estudiosos começaram a testar as hipóteses do agenda-setting. Muitos trabalhos foram feitos ou orientados pelos próprios McCombs e Shaw ${ }^{3}$. A nossa intenção, nesse momento, não é contar toda a história da evolução dessas pesquisas, trabalho já feito por outros pesquisadores (McCombs, 1993; Wolf, 1992; Barros Filho, 1995), mas é necessário explicar em que contexto elas surgiram.

As hipóteses do agenda-setting fazem parte dos estudos norte-americanos em comunicação, pertencentes ao paradigma funcionalista, que reúne pesquisas preocupadas em analisar e detectar as funções dos meios e os efeitos causados sobre a audiência. Inicialmente, o paradigma foi dominado pela teoria da agulha hipodérmica, defensora da tese de que os meios de comunicação de massa são extremamente poderosos, com efeitos absolutamente previsíveis na audiência. Um dos grandes representantes desta perspectiva é Harold Lasswell. Imerso nos efeitos da propaganda de guerra, que passou a estudar, este cientista político da Universidade de Chicago defende que "a audiência é visada como um alvo amorfo que obedece cegamente ao esquema estímulo-resposta" (Mattelart, 1999, p. 37). Esta teoria ficou em grande evidência até o início dos anos 40, quando Paul Lazarsfeld começa a defender que os efeitos dos 
meios de comunicação são limitados.

Lazarsfeld argumenta que líderes de opinião e elites bem informadas ocupam o primeiro passo na estrutura da formação da opinião pública e são os transmissores de novas idéias e valores ao público menos informado. Ele sistematiza e impulsiona a teoria dos usos e gratificações, defendendo que o receptor consome as mensagens da mídia para, basicamente, quatro razões: se divertir; facilitar a interação social; explorar a realidade e reforçar os valores coletivos; vigiar, através dos meios, e adquirir informações sobre o desenvolvimento de opiniões relativas aos temas públicos (Sampedro Blanco, texto inédito). No seu famoso livro The People's Choice (Nova York: Duel, Sloan and Plarce, 1944), Lazarsfeld descreve a pesquisa que fez no distrito de Eric County, em Ohio, típica região norte-americana. Foram entrevistados 600 pessoas, previamente escolhidas, para verificar possíveis efeitos dos meios de comunicação na definição do voto entre os candidatos Wendel Wilkie e Franklin Roosevelt. O pesquisador da Universidade de Columbia concluiu que alguns entrevistados eram influenciados pelas mensagens dos meios de comunicação de massa, mas isso não significava, necessariamente, um efeito poderoso porque o eleitor já tinha uma predisposição latente, precisando apenas cristalizá-la, o que poderia ser feito através da manifestação desta vontade na mídia.

"Outros haviam decidido como agir desde o início da campanha e essas decisões eram confirmadas pela escolha constante e partidária de um material adicional fornecido pelos veículos. Finalmente, para um punhado de eleitores, as decisões iniciais de voto foram alteradas, e a campanha conseguiu converter o indivíduo de um partido para outro." (citado em De Fleur, 1971, p. 178 a 179).
O segundo trabalho publicado por Lazarsfeld veio assinado junto com Elihu Katz, em 1955 (Personal Influence: The Part Played by People in the Flow Mass Communication. Free Press, Glencoe, III, 1970). Desta vez, a pesquisa se volta para o comportamento dos consumidores de moda e formas de lazer. Estudando os processos de decisão individuais de 800 mulheres de uma cidade de 60 mil habitantes (Decatur, Illinois), redescobrem como no estudo procedente - a importância do grupo primário.

"É o que lhes permite apreender o fluxo de comunicação como um processo em duas etapas, na qual o papel dos líderes de opinião se revela decisivo. É a teoria do two-step-flow. No primeiro degrau estão as pessoas relativamente bem informadas, porque diretamente expostas à mídia; no segundo, há aquelas que freqüentam menos a mídia e dependem dos outros para obter informação." (citado em Mattelart, 1999, p. 47 e 48)

Quando o conceito de agendasetting foi exposto pela primeira vez pelos dois pesquisadores americanos, a teoria dos efeitos limitados, em grande parte impulsionada por Lazarsfeld, dominava os estudos de comunicação nos princípios dos anos 60 . Ainda hoje, alguns pesquisadores discutem se o agendasetting se contrapõe aos efeitos limitados ou os reafirma. Traquina (1995, p.189), por exemplo, defende que as hipóteses do estabelecimento da agenda surgem para se contrapor à teoria dos efeitos limitados, mas o próprio McCombs (1996, p.20) enfatiza que as suas pesquisas atestam que os efeitos são limitados. Para comprovar a sua posição, cita o que considera "o melhor dos trabalhos de campo acerca da influência do estabelecimento de uma agenda-setting nos meios informativos", referindo-se ao trabalho de Brosius e Kepplinger (1990). Ambos fizeram, durante um ano, uma 
comparação da análise do conteúdo dos programas de notícias mais importantes da televisão da Alemanha Ocidental com pesquisas semanais de opinião pública, sobre os assuntos que os cidadãos alemães consideravam mais importantes. Em cinco aspectos, encontraram poderosos efeitos do estabelecimento da agenda: nos assuntos referentes à energia, relações com a Alemanha Oriental, defesa, meio ambiente e política da Comunidade Européia. Em outros aspectos, a opinião pública prevalecia sobre a cobertura das notícias ou simplesmente não existia correlação entre as partes. "Esta configuração de resultados estabelece que os meios informativos não são o monolítico 'big brother' que rege totalmente a atenção pública", escreve McCombs (1996, p. 19 e 20).

Traquina defende que a comprovação das hipóteses do agendamento retoma o poder do texto informativo e atesta um poder midiático muito superior ao poder inicialmente postulado pelos autores das pesquisas. Citando uma série de pesquisas que comprovam a estreita relação entre a agenda dos meios noticiosos e a agenda pública, Traquina não é o único a argumentar que o agendamento contesta a teoria dos efeitos limitados. Bregman também acredita que a função da agenda nasce de uma preocupação em superar a teoria dos efeitos limitados, em pelo menos dois níveis: no campo da sociologia eleitoral (a importância e o aumento do eleitorado flutuante obrigam a investigação das causas desta evolução e os meios parecem ocupar um lugar importante neste processo) e no fato de que a comunicação massiva passa a ser uma preocupação dos jovens doutores em comunicação, pois até então $o$ assunto era dominado por psicólogos sociais (Levin e Hovland), estudiosos da política (Lasswell) e de sociólogos (Lazarsfeld). (Bregman, 1998, p.210 e 211).

Bregman acredita que, por terem experiência em jornalismo impresso e televisivo, estes novos investigadores sabem que os meios geram efeitos, apesar dos fundadores do agenda-setting terem indicado apenas efeitos limitados. Aqui parece residir o porquê de muitos estudiosos acreditarem que o agendamento reforça a teoria de efeitos poderosos. Alguns estudos começaram a detectar efeitos significativos produzidos pelas mensagens dos meios de comunicação. Além disso, é mesmo possível verificar diferenças entre as conclusões de Lazarsfeld e as de McCombs.

Para tentar resolver este problema, é significativo recorrer a um texto de Elihu Katz, que permanece como um dos principais representantes contemporâneos da teoria dos efeitos limitados. Katz fez uma divisão das correntes teóricas que estão contestando os efeitos limitados. Incluiu no que chama de paradigma institucional o grupo que faz uma crítica explícita ao modelo dos efeitos limitados; no paradigma crítico os que substituem os efeitos limitados por uma teoria de efeitos diretos e poderosos e no paradigma tecnológico o grupo que se julga capaz de traduzir esta teoria em um programa de investigação. O modelo institucional, ao qual pertence o agenda-setting, sustenta que a mídia nos diz em que temos que pensar. No paradigma crítico, a mídia tem o poder de nos dizer em que não há o que pensar. No paradigma tecnológico, a mídia talvez tenha o poder de dizer como devemos pensar e a que grupo pertencer (Katz, 1998).

Katz considera o primeiro grupo, o do paradigma institucional, como o menos radical e que teria em McCombs o seu principal representante. O paradigma crítico estaria muito menos disposto a respeitar os efeitos limitados. Todd Gitlin e Elisabeth Noelle-Neumann são considerados como dois dos mais significativos autores desta perspectiva. O terceiro grupo seria representado por McLuhan, Innis e Carey, com estudos valorizando o efeito dos meios de comunicação na organização social, como a nova tecnologia do papiro, 
do telégrafo ou da imprensa modificou o mercado, por exemplo.

Embora esta divisão de Katz seja passível de críticas, desta forma parece mais fácil entender por que existem duas posições aparentemente opostas (a de McCombs dizendo que o agenda-setting reafirma a teoria dos efeitos limitados e a de Traquina defendendo que as pesquisas apontam efeitos poderosos) sobre uma mesma corrente teórica. No decorrer dos estudos, os pesquisadores foram encontrando efeitos diferentes, demonstrando que as hipóteses ainda estão em permanente construção. Para Katz, os três grupos acabam fazendo um grande grupo de teorias complementares em permanente busca de uma conceituação adequada para a idéia de efeito e que, "apesar de algumas asperezas ocasionais", todos são competentes. Katz diz que, mesmo quando as teorias não parecem complementares, acabam convergindo para as conclusões já apontadas por Lazarsfeld (Katz, 1998, p.100).

\section{Do agenda-setting ao framing}

Antes de tratar sobre o conceito de framing, parece necessário especificar um pouco mais dos estudos sobre o agenda-setting. Ao contrário dos desdobramentos e dos possíveis efeitos, a sua definição em si é simples. "As pessoas agendam seus assuntos e suas conversas em função do que a mídia veicula. É o que sustenta a hipótese" (citado em Barros Filho, 1995, p. 169). Como diz Shaw, a formulação clássica da hipótese defende que, "em conseqüência da ação dos jornais, da televisão e dos outros meios de informação, o público sabe ou ignora, presta atenção ou descura, realça ou negligencia elementos específicos dos cenários públicos". As pessoas, continua ele, teriam a tendência de incluir ou excluir dos seus próprios conhecimentos aquilo que a mídia inclui ou exclui do seu próprio conteúdo. Além disso, o público tenderia a atribuir àquilo que este conteúdo inclui uma importância que reflete de perto a ênfase atribuída pela mídia aos acontecimentos, aos problemas e às pessoas. O pressuposto fundamental do agenda-setting é que a compreensão que as pessoas têm de grande parte da realidade social Ihes é fornecida, por empréstimo, pela mídia (citado em Wolf, 1986. p.128).

Os estudos sobre o agenda-setting ganham cada vez mais importância justamente porque os meios de comunicação de massa assumem um papel fundamental na disseminação das informações no mundo contemporâneo. Ainda que a comunicação interpessoal tenha o seu papel, atualmente, é difícil que um grande número de pessoas fique sabendo de um acontecimento somente através das conversas com os seus familiares, amigos ou colegas de trabalho. Para um fato ser conhecido pela sociedade, especialmente nos grandes centros urbanos, é vital que ele transite nos meios de comunicação. Embora não se detenham no conceito de agendamento, esta é uma posição que vem sendo adotada por vários pesquisadores. ${ }^{4}$

Direcionando o foco para a cobertura eleitoral, McCombs e Shaw formulam as hipóteses fundamentais do agenda-setting: em uma campanha eleitoral, os eleitores recebem dos meios de comunicação a maior parte das suas informações; os eleitores conhecem novos elementos da informação, mas nem todos são igualmente capazes de interpretar e usar todos os pontos de vista; os eleitores conhecem e se informam de acordo com a insistência com que os meios falam e dão conta dos problemas debatidos durante a campanha (citado em Bregman, 1998, p. 213).

Os resultados podem ser resumidos em quatro pontos: grande parte das informações está dedicada à análise do dia da campanha, o que os jornalistas norte-americanos chamam de "corrida de cavalos"; surge uma visível correlação entre 
a importância dada pelos meios a certas posturas e a importância que os eleitores atribuem a estes temas; os eleitores que no começo não estão fortemente ligados a um candidato são mais atentos para a totalidade das informações (citado em Bregman, 1998, p.213).

Aqui aparecem as primeiras diferenças entre McCombs e Lazarsfeld. Enquanto os estudiosos do agendamento nos dizem que os eleitores indecisos e flutuantes estão atentos ao conteúdo das informações e parecem não ter preconceitos e nem juízos preestabelecidos, Lazarsfeld defende que o alto grau de exposição aos meios de comunicação, que é uma condição prévia para eventuais efeitos da agenda, se associa com um alto grau de interesse pela política. Neste sentido, a exposição aos meios somente poderia intervir no sentido de reforçar as opiniões já estabelecidas. As conclusões de McCombs e Shaw, pelo contrário, dizem que os indivíduos que ainda não escolheram os seus candidatos se inclinam mais por seguir a campanha através dos meios de comunicação e, por isso, podem se sentir atraídos por este ou aquele problema e, desta forma, pode ser beneficiado o candidato que está em mais evidência na mídia. Tudo isso pode contribuir para influenciar o resultado (Bregman, 1998, p.213 e 214).

McCombs e Shaw fizeram uma segunda pesquisa em 1972, em Charlotte Ville, uma cidade em plena expansão, com 354 mil habitantes, a maioria oriunda de vários lugares do país. Foram escolhidos 380 eleitores, acompanhados por cinco meses.

Entre as principais conclusões estão os seguintes pontos: à medida que a campanha avança, a atenção dos eleitores amplia, e eles, através da mídia, passam a formar um conjunto de informações mais ou menos comuns. Este conjunto produz a base para a formação de uma atitude ou uma mudança de atitude diante dos candidatos; existe o duplo fluxo informacional de Lazarsfeld, defensor de que a informação também é mediada através dos líderes de opinião; há uma correlação entre a agenda da mídia e a do receptor, mas também a agenda do receptor pode e acaba influenciando a agenda da mídia; um tipo de mídia agenda outro, com os meios impressos tendo mais importância que os eletrônicos; o agendamento só ocorre de maneira eficiente quando houver um alto nível de percepção de relevância para o tema e, ao mesmo tempo, um grau de incerteza relativamente alto em relação ao domínio do mesmo; a influência do agendamento depende do grau de exposição a que o receptor está exposto, ao tipo de mídia, do grau de relevância e interesse que este receptor dá ao tema, ao grau de incerteza e aos diferentes níveis de comunicação interpessoal que ele desenvolve (citado em Hohlfeldt, 1997, p. 47 a 49).

Funkhouser publica, em 1973, um estudo que explora os anos 60 e estuda as relações entre os acontecimentos e as posturas da década, a cobertura realizada pelos meios de comunicação e a sua percepção por parte da opinião pública. Utilizou sondagens de opinião do Instituto Gallup, indicadores estatísticos e analisou três semanários (Time, Newsweek e U.S. News) e o jornal Word Report. Concluiu que se os meios prestarem atenção a uma postura, aumentará a importância que a opinião pública dará a ela. Descobriu que existia uma correspondência substancial entre a opinião pública e a cobertura das notícias, mas o mais importante do trabalho foi ter detectado que existe uma escassa correspondência em alguns dos temas publicados na imprensa com os indicadores estatísticos da realidade. A cobertura da imprensa e a preocupação pública sobre - Vietnã, a intranqüilidade nos campos universitários e os distúrbios cívicos durante os anos 60, por exemplo, cresceram muito antes de existirem indicadores de realidade, tais como tropas enviadas para o Vietnã e número de manifestantes e distúrbios civis. Ou seja, a importância quantitativa 
das informações fornecidas pelos meios não corresponde, necessariamente, com a importância real dos acontecimentos (Bregman, 1998, p.215 e McCombs, 1996, p.19).

Framing: herdeiro do agenda-setting

Há pelo menos três caminhos que poderemos percorrer para a análise dos estudos sobre o agendamento, divididos entre as pesquisas sobre o estabelecimento da agenda do público (tendência que vimos até aqui), o estabelecimento da agenda política, conhecida como policy agenda-setting, e a construção da agenda, a chamada agenda building. A primeira linha trata sobre o efeito que os meios de comunicação exercem sobre as percepções da opinião pública nas diversas questões sociais. É a relação casual entre a agenda informativa e a agenda do público.

A segunda linha estuda como os meios condicionam as percepções dos próprios representantes políticos. É a relação casual entre a agenda informativa e a agenda política, ou dos profissionais da política. A construção da agenda, ou agenda building, estuda como e quem determina as agendas, quem tem o poder de controlar a agenda e como isso é realizado. $^{5}$

Os mais recentes estudos sobre 0 agendamento têm concluído que a mídia não tem apenas o poder de nos oferecer 0 leque de assuntos pelos quais iremos nos preocupar e conversar. Além de estabelecer esta agenda interpessoal, os meios de comunicação também teriam o poder de nos dizer como devemos pensar os temas existentes na agenda da mídia. Os pesquisadores têm explicado isso através do conceito do framing, ou enquadramento. Embora afirme com um certo vigor o poder da mídia, chegando muito próximo da teoria dos efeitos poderosos, como já detectou Katz, chamando esta corrente de paradigma crítico, estes trabalhos são os principais herdeiros do trabalho de McCombs. Este, inclusive, já admitiu e aceitou tais pesquisas e as vem incorporando nos seus estudos.

"Agenda-setting é considerada mais do que a clássica asserção de que as notícias nos dizem sobre o que pensar. As notícias igualmente nos dizem como pensar acerca disso. A seleção de objetos para a atenção e a seleção dos enquadres pensados acerca destes objetos são o ponto forte do papel do agendasetting."(McCombs, 1993, p.62).

Para Traquina, este tipo de citação mostra que ocorreu uma considerável mudança nos postulados iniciais das hipóteses do agenda-setting. De um efeito limitado estaria sendo defendido, no mínimo, algo além disso. $\mathrm{O}$ argumento de Cohen, de que os meios de comunicação teriam apenas o poder de nos dizer em que pensar, "foi virado do avesso porque novas investigações, explorando as conseqüências do agenda-setting e do enquadramento, sugerem que os media não só nos dizem em que pensar, mas também como pensar nisso, e conseqüentemente o que pensar" (Traquina, 1995, p. 204 e 205).

Robert Entman, atualmente, pode ser considerado um dos principais estudiosos do framing. Ele nos diz que o poder do agenda-setting está entre a distinção sobre quais assuntos eu estou pensando e o que eu penso sobre determinada coisa ou assunto (Entman, 1989). Ele defende que "the concept of framing consistently offers a way to describe the power of a communicating text. Analysis of frames illuminates the precise way in which influence over a human consciousness is exerted by the transfer (or communication) of information from one location - such as a speech, utterance, news report, or novel - to that consciousness." (Entman, 1993, p.1 a 8). Neste mesmo texto, diz que com 
o framing é possível atuar politicamente, definir problemas, diagnosticar causas, fazer um julgamento moral e sugerir remediações.

Para Entman, através do framing é possível verificar quem tem o poder no texto comunicativo porque conseguimos chegar nas origens da mensagem, na verdadeira autoria da informação. Esse poder é o de como pensar o mundo e o framing passa a ser uma ferramenta empregada por aqueles que têm poder para transmitir o seu jeito de pensar para os demais. $O$ framing, de um modo geral, é como temos que pensar os temas já estabelecidos pela agenda.

Qualquer que seja o seu uso específico, diz Entman, o conceito de framing consiste em oferecer o modo de descobrir o poder do texto comunicativo. As análises passam a detectar qual é a influência sobre a consciência, que é exercida na transferência da informação. Produzir um enquadramento é selecionar alguns aspectos da realidade percebida e dar a eles um destaque maior no texto comunicativo, gerando interpretação, avaliação moral e/ou tratamento recomendado para o item descrito.

Para identificar o enquadramento de uma reportagem, Entman indica que primeiro é preciso ir em busca da definição do problema apresentado, verificando se ele é político ou econômico, por exemplo. Verificar se há ou não personalização do problema, se a economia é colocada ou não como um ente, por exemplo. Feito isso, é necessário identificar as causas do problema apresentado na reportagem, quais são os seus atores, a quem está sendo creditada a solução deste problema e, afinal, quais são as suas soluções. Por último, é possível identificar a avaliação moral do problema, se o momento crítico é positivo ou negativo.

Entre as várias explicações do poder do framing, Entman cita uma pesquisa feita por Kahneman e Tversky. Eles fizeram a seguinte experiência: imagine que 0 governo dos Estados Unidos precise anunciar à população que está em ação uma grave doença que atinge $600 \mathrm{mil}$ pessoas. Mas o governo tem projetos para combatê-la. No entanto, está em dúvida sobre quais dos projetos vai colocar em prática. Se adotar o projeto A, 200 mil pessoas vão ser salvas. Se adotar o projeto $\mathrm{B}$, um terço das 600 mil pessoas atingidas serão salvas e outros 2/3 vão morrer. Em quais destes dois projetos você vota? $72 \%$ optaram pelo projeto $A$ e $28 \%$ no programa B. As duas opções são idênticas, apenas muda a forma como o problema é colocado.

Para Entman, o exemplo ilustra que o frame determina o caso que é mais notícia para as pessoas, como elas entendem e relembram o processo e de como elas valorizam e fazem uma das opções. Para ele, a noção do framing implica que ele tenha um efeito comum em uma larga faixa de receptores. Entretanto, frisa, ele não tem um efeito universal em todos (Entman, 1993, p. 2).

Ao se referir aos frames nas notícias políticas, Entman lembra que os políticos são obrigados a competir com outros políticos e com os jornalistas para criar novos enquadramentos. Nestes lugares (da política), o framing acaba ascendendo como uma das maiores funções inseridas sobre o poder político, pois o frame no texto informativo é a marca do poder (Entman, 1993, p. 5).

Mas como identificar os enquadramentos? Entman também se preocupou com esta operacionalização e fez várias pesquisas. Uma delas analisa o framing das revistas Time e Newsweek, dos jornais New York Times e Washington Post e da rede de televisão CBS sobre a queda de dois aviões: o da Korean Air Lines, em setembro de 1983 e da Iran Air, em julho de 1988. Neste texto, Entman (1991) diz que os novos frames são construídos e personificados nas palavras-chave, metáforas, conceitos, símbolos e imagens visuais enfatizadas na notícia narrada. Já que a narrativa não consiste em apenas 
palavras e figuras, diz ele, o frame pode ser detectado pela sondagem de palavras em particular e em imagens visuais que aparecem insistentemente na narrativa (Entman, 1991, p.2).

A teoria do framing, alerta Entman, não pretende defender a tese de que a audiência recebe passivamente as mensagens. Ele argumenta que os membros da audiência são teoricamente livres para tirar seu próprio significado das mensagens da mídia. No entanto, mostra que o caso dos incidentes com os dois aviões indica que quando há escassas notícias feitas para desafiar o frame dominante, uma posição dita autorizada tende a penetrar no texto informativo, tal como frames dominantes tendem a obscurecer totalmente alguma informação que seja oposta.

O pesquisador diz que os jornalistas, às vezes, resistem ou desafiam abertamente a linha oficial, tal como a oposição às elites. Mas, nestes dois casos analisados, o enquadramento das notícias coincidiu justamente com os interesses e as estratégias empregadas pela administração do presidente Ronald Reagan. Entman sugere que a condição para promover a administração do controle de outros frames, versus mais autonomia do controle jornalístico, merece ser mais pesquisada, especialmente desde que a autonomia jornalística passou a ser tão criticada na teoria da democracia (Entman, 1991, p.19 e 20).

A hipótese de Entman é de que, quando um simples frame domina inteiramente a narrativa, politicamente uma expressiva maioria deverá chegar a ter o mesmo entendimento sobre o assunto noticiado.

Variáveis do enquadramento

Muito antes de Entman, o enquadramento foi analisado por Erving Goffmann (1975), mas de maneira diferenciada. Enquanto o primeiro estuda o enquadramento feito pelos meios de comunicação, o segundo se preocupa com o enquadramento feito pela audiência. Segundo Goffmann, para entender este processo é preciso invocar o "esquema de interpretação" que permite os indivíduos "localizar, perceber, identificar e etiquetar" as informações ao seu redor. Ainda que as notícias utilizem formas convencionais, tal como o estilo da pirâmide invertida, os integrantes de uma audiência recolhem os dados sobre um candidato ou um tema e o recompõem em uma narrativa casual ou em uma história que reflita seu próprio ponto de vista ou enquadramento. Esta narrativa vai servir depois para a compreensão de outras histórias informativas (citado em McLeod, 1996, p.190).

Há uma série de outros autores que se dedicam a estudar o enquadramento realizado pela audiência, que pode ser vista a partir de três perspectivas diferentes: a crítica, com David Morley, a cultural com Liebes e Katz e a construtivista com Gamson. Em geral, os autores defendem que o enquadramento de qualquer integrante de uma audiência pode estar em consonância com o pacote informativo, assim como em ativa oposição ao enquadramento midiático, ou ainda pode ter um aspecto independente do formato informativo e do seu conteúdo (citado em McLeod, 1996, p.191).

Entre os autores que estudam o enquadramento feito pela audiência, vale destacar o trabalho de Gamson e Modigliani (1989), dentro da linha construtivista. Eles analisam a formação de frames cognitivos em vários públicos e defendem que há uma ressonância do jornalista em relação com a audiência. Gamson, considerado um dos mais interessantes estudiosos da recepção, concluiu que as pessoas guardam recortes de notícias de determinados assuntos. Estes recortes seriam as formas semelhantes com que os assuntos vão sendo tratados pelos meios de comunicação. Com isso, a audiência 
forma certos "pacotes" para conseguir explicar o seu ponto de vista.

Os enquadramentos, para estes dois autores, são transmitidos através de cinco dispositivos: as metáforas, os exemplos históricos, as citações curtas, as descrições $\mathrm{e}$ as imagens. Eles diferem de Entman porque não se preocupam tanto com o conteúdo informativo das reportagens, mas com o comentário interpretativo que as rodeia. Eles lembram que as reportagens de tevê estão cheias de chavões, metáforas e outros dispositivos que fornecem uma forma rápida de sugerir a narrativa que está por baixo do publicado, que não está totalmente manifestada.

Gamson e Modigliani analisaram como as pessoas formam as suas opiniões sobre a energia nuclear. Basicamente, poderiam ser divididas da seguinte forma: entre as que preferem as energias brancas; as que aceitam a energia nuclear, desde que muito bem controlada; as que dizem não para a energia nuclear alegando que ela não é suficiente rentável para resolver os problemas; e as que dizem que ela é inevitável, assim como a globalização. Os pesquisadores encontraram estes mesmos frames na forma como os jornalistas americanos empacotaram as notícias sobre o assunto de 1945 até o fim da pesquisa, publicada em 1989. Por fim, eles chegaram a uma conclusão simplória: a mídia influenciou a opinião pública, mas também a refletiu.

Vários autores se dedicaram a estudar o enquadramento das notícias como uma forma de manter a hegemonia de um dado grupo, transmitindo as informações de acordo com a ideologia dominante. Apesar do termo ideologia estar tão fora de moda ${ }^{6}$, a contribuição destes pesquisadores é essencial. Entre eles, talvez um dos mais significativos seja Todd Gitlin (1980) "um dos mais virulentos críticos da teoria dos efeitos limitados"(Dayan, 1998, p. 104 a 106). Gitlin define os enquadramentos como "padrões persistentes de cognição, interpretação, apresentação, seleção, ênfase e exclusão, através dos quais aqueles que trabalham os símbolos organizam geralmente o discurso, tanto verbal como visual" (citado em Hackett, 1993, p. 120 e 121).

Ao analisarem as redes de tevês americanas e italianas, Hallin e Mancini recorrem a Gitlin e dizem que, "mesmo ao refletir a sociedade, os media enquadramna: eles refletem para a sociedade não apenas acontecimentos, não apenas uma realidade não imediata, mas um conceito particular de política encarnada na vida política dessa sociedade". Como exemplo, usam a conclusão do estudo atestando que a atenção das notícias americanas é endereçada, em primeiro lugar, às esferas institucionais e administrativas. Na Itália, a ênfase está na esfera política porque os jornalistas concedem mais espaço para o processo de debate político e ideológico e aos atores envolvidos. (Hallin e Mancini,1993, p.311).

Para fugir da teoria da pura conspiração das elites, vale ressaltar, assim como Hackett, que um enquadramento não é necessariamente um processo consciente por parte dos jornalistas. "Pode muito bem ser o resultado da absorção inconsciente de pressuposições acerca do mundo social no qual a notícia tem de ser embutida de modo a ser inteligível para o seu público pretendido" (Hackett, 1993, p.121).

O mesmo faz Hall, chamando a atenção para as rotinas produtivas para observar como a mídia reproduz as definições dos poderosos sem estar, num sentido simplista, ao seu serviço. Para ele, "os media não se limitam a "criar" as notícias; nem se limitam a transmitir a ideologia da "classe dirigente" num figurino conspiratório. $\mathrm{Na}$ verdade, sugerimos que, num sentido crítico, os media não são freqüentemente os primary definers de acontecimentos noticiosos; mas a sua relação estruturada com o poder tem o efeito de os fazer representar não um papel crucial, mas secundário, ao reproduzir as definições daqueles que têm 
acesso privilegiado, como de direito, aos media como "fontes acreditadas". Nesta perspectiva, no momento da produção jornalística, os media colocam-se numa posição de subordinação estruturada aos primary definers." (Hall, 1993, p.228 a 229).

Mesmo com estas ressalvas, não podemos esquecer que a hipótese da "propaganda framework", diretamente ligada com o conceito de enquadramento realizado pelos meios de comunicação e facilmente identificada com as noções de hegemonia e ideologia, também foi comprovada. Edward Herman explica a hipótese: "quando surgem situações em que podem ser "marcados pontos contra países inimigos" ou idéias ameaçadoras, os meios de comunicação de massa serão freqüentemente ativos em "campanhas publicitárias" de grande intensidade e paixão. Pelo contrário, quando acontecimentos muito semelhantes ocorrem em países amigos, os media mostrarão interesse pelas circunstâncias especiais envolvidas e prosseguirão uma política de negligência benigna" (Herman, 1993, p.217). Ele aplicou a hipótese fazendo uma análise da cobertura do New York Times sobre a eleição em El Salvador e na Nicarágua, ambas realizadas em 1984. Embora a Nicarágua estivesse em melhores condições eleitorais do que El Salvador, a cobertura noticiosa deu a El Salvador uma situação triunfante de democracia e para a Nicarágua uma experiência desacreditada pela intransigência e controles totalitários sandinistas (Herman, 1993, p. 221 a 223).

$\mathrm{O}$ estudo do enquadramento feito pela mídia também pode revelar como os meios de comunicação rotulam determinados movimentos sociais ou eventos. Em um vasto estudo sobre como a imprensa espanhola tratou o movimento Objeção de Consciência $(\mathrm{OC})$, que lutou para acabar com o alistamento militar obrigatório na Espanha, Sampedro verificou que, durante 1988, em quase metade dos parágrafos do jornal $A B C$ e em uma quinta parte do jornal El País, o movimento foi tratado como terrorista. "Este emparelhamento de temas tão distantes em sua natureza poderia desorientar tendenciosamente os leitores a apoiar os discursos das elites que identificaram os insubmissos com os terroristas. Sem dúvida, terrorismo e OC são antagônicos." (Sampedro, 1997, p. 268 a 269).

Conservando este tom crítico, $\mathrm{M}$. Gurevitch e J. G. Blumer também se destacam no estudo do enquadramento. Eles dizem que a mídia se centra em correntes majoritárias, colocadas politicamente pelo sistema bipartidarista (referindo-se, obviamente, aos países com este sistema) economicamente pelo imperativo do capitalismo da empresa privada e, culturalmente pelos valores da sociedade do consumo. Gitlin também vai dizer que os grupos políticos minoritários estão marginalizados e são etiquetados como "desviados" e que se dá pouca cobertura para as audiências menos atrativas, como os pobres e os anciãos. 0 resultado é que o público fica carente de alternativas políticas e incapaz de oferecer, inclusive, seu próprio ponto de vista a respeito, uma vez que um diálogo só é eficaz quando a mídia comparar diversos pontos de vista de forma sistemática e alternar os seus enquadramentos (citado em McLeod, 1996, p. 206).

Também dialogando com os estudos sobre o enquadramento, lyengar dividiu as reportagens entre cobertura temática e episódica. Esta última caracterizaria grande parte do jornalismo atual e o enquadramento utilizaria informes sobre estudos de caso ou eventos e exemplos concretos. Já o enquadramento temático teria um conteúdo geral muito mais abstrato. lyengar concluiu que as histórias temáticas aumentavam a atribuição de responsabilidade ao governo e à sociedade, enquanto os tratamentos episódicos diminuíam globalmente a responsabilidade do sistema. (citado em McLeod, 1996, 184).

Bennett fez quase a mesma distinção e sugeriu quatro defeitos comuns existentes 
na cobertura episódica: a personalização, que, segundo ele, impede uma correta apreciação dos temas e uma maior escala social em termos de atores individuais; a fragmentação, ou a apresentação da informação entre problemas históricos desconectados entre si; a dramatização, que modifica os critérios de seleção, permitindo a publicação de um fato dramático, mesmo de menor importância, no lugar de um fato de mais importância para o conjunto da audiência, fazendo com que se publique este último se ele alcançar proporções críticas; e a normalização, ou dissimulação de problemas procedentes do próprio sistema político, reforçando as estruturas de poder existentes (citado em McLeod, 1996, 184).

\section{Considerações finais}

Com a retomada destes textos, fica claro que estamos distantes de um consenso sobre a principal discussão proposta por este artigo. Divergências semelhantes foram apontadas no início do desenvolvimento do conceito do agenda-setting (alguns defendendo que ele reafirma a teoria dos efeitos poderosos e outros dizendo que ele reafirma o paradigma dos efeitos limitados) e também perduram nos estudos sobre os enquadramentos. Isso não impediu que os trabalhos apresentassem considerações importantes. As pesquisas comprovam os momentos em que a mídia exerceu efeitos significativos tanto no estabelecimento da agenda dos receptores como na assimilação do enquadramento dominante verificado nos meios de comunicação. No entanto, somente destacar estes estudos para defender a tese de que a teoria dos efeitos limitados está sendo contestada por esta corrente teórica não é suficiente, pois outras pesquisas relativizam o poder dos meios de comunicação tanto no estabelecimento de agendas como de enquadramentos.

\section{Notas}

1 Jornalista pela UNISINOS, Mestre em Comunicação e Cultura Contemporâneas pela Facom/UFBA, professor substituto da Facom/UFBA e coordenador do curso de jornalismo da Faculdade Dois de Julho, de Salvador.

20 mesmo texto, com o título A redescoberta do poder do jornalismo: análise da evolução da pesquisa sobre 0 conceito de agendamento (agenda-setting) foi publicado este ano no Brasil. Ver Traquina, Nelson. 0 estudo do jornalismo no século XX. São Leopoldo: Editora Unisinos, 2001.

3 É impressionante o número de trabalhos que utilizam 0 conceito do agenda-setting. Traquina, em texto publicado em 1995, diz que o número já era de 200 artigos e livros. 0 número, hoje, deve ser bem maior. Basta acionar um site de busca na internet e é possível carregar, em pouco tempo, mais de 500 referências sobre 0 assunto.

4 Esta preocupação, direcionada para as novas formas de se fazer política na contemporaneidade, é central no pensamento de RUBIM, Albino Antonio Canelas. Mídia e Política no Brasil. João Pessoa: Editora Universitária UFPB, 1999.

5 Esta distinção pode ser vista em vários trabalhos, tais como: SAMPEDRO BLANCO, Victor. Movimientos sociales: debates sin mordaza: Desobediencia civil y servicio militar (1970-1996). Madrid: Centro de Estudios Constitucionales, 1997, p. 35. ROGERS, Everett M. "The anatomy of agenda-setting research". Journal of Communication, 43 (2), Spring, 1993.

60 termo é utilizando remetendo a Lipovetsky (1989), defensor da idéia de que estamos no império da forma moda, que também atinge a ideologia, agora marcada pela flexibilidade, descontração e possibilidade de revisão a qualquer momento, ao contrário da ideologia totalizante e dogmática do século XIX. Ver Lipovetsky, Gilles. 0 império do efêmero. São Paulo: Companhia das Letras, 1989

Referências

BARROS FILHO, Clóvis. Ética na comunicação: da informação ao receptor. São Paulo, Moderna, 1995.

BENNETT, W. L. News: the politics of illusion. Nova York: 
Longman, 1988.

BREGMAN, Dorine. "La función de agenda: una problemática en transformación". In: FERRY, Jean-Marc e outros. El nuevo espacio público. Barcelona: Gedisa, 1998.

BROSIUS, H.B. e KEPPLINGER, H. M. "The agenda-setting function of television news: Static and dynamic views". In Communication Research, 17, 1990, p. 183 a 211.

DAYAN, Daniel. "Acerca de la teoria de los efectos limitados". In: FERRY, Jean-Marc e outros. El nuevo espacio público. Barcelona: Gedisa, 1998.

DE FLEUR, Melvin L. Teorias de comunicação de massa. Rio de Janeiro: Zahar Editores, 1971.

ENTMAN, Robert M. "Framing: toward clarification of a fractured paradigm". In: Journal of Communication 43 (4), Autumn, New York: Oxford University, 1993, p. 1 a 8

ENTMAN, Robert M. "Framing U. S. Coverage of International News: Contrasts in Narratives of the KAL and Iran Air Incidents". In: Journal of Communication, 1991 (c), Oxford University

ENTMAN, Robert M. Democracy without citizens - media and the decay or american politics. New York: Oxford University Press, 1989.

GAMSON, William A. e MODIGLIANI, Andre. "Media discourse and public opinion on nuclear power: a cons-tructionist approach". American Journal of Sociology, University of Chicago, 1989.

GITLIN, Todd. The whole word is watching: mass media and the making and unmaking of the New Left. Berkeley, CA: University of California Press, 1980.

GOFFMANN, Erving. Frame analysis. Nova York: Harper y Row, 1974.

GUREVITCH, M e BLUMLER, J.G. "Political communication systems and democratic values". In: LICHTENBERG, J (org.) Democracy and the mass media. Cambridge: Cambridge University Press, 1990, p. 269 a 289.

HACKETT, Robert A. "Declínio de um paradigma? A parcialidade e a objectividade nos estudos dos media noticiosos". In: TRAQUINA, Nelson. Jornalismo, Questões, Teorias e "Estórias". Lisboa: Vega, 1993.

HALLIN, Daniel C. e MANCINI, Paolo. "Falando do presidente: a estrutura política e a forma representacional nas notícias televisivas dos Estados Unidos e da Itália". In: TRAQUINA, Nelson. Jornalismo, Questões, Teorias e "Estórias". Lisboa: Vega, 1993.

HALL, Stuart e outros. "A produção social das notícias: 0 mugging nos media". In: TRAQUINA, Nelson. Jornalismo, Questões, Teorias e "Estórias". Lisboa: Vega, 1993.

HERMAN, Edward S. "A diversidade de notícias: 'marginalizando' a oposição". In: TRAQUINA, Nelson. Jornalismo, Questões, Teorias e "Estórias". Lisboa: Vega, 1993

HOHLFELDT, Antonio. "Os estudos sobre a hipótese do agendamento". In: Revista Famecos. Porto Alegre: Edipucrs, número 7, 1997.

KATZ, Elihu. "La investigación en la comunicación desde Lazarsfeld". In: FERRY, Jean-Marc e outros. El nuevo espacio público. Barcelona: Gedisa, 1998.

LASSWELL, Harold . "A estrutura e a função da comunicação na sociedade". In: COHN, Gabriel (org.) Comunicação e indústria cultural. São Paulo: Nacional, 1971, p. 105 a 117

LAZARSFELD, Paul e MERTON, Robert. "Comunicação de massa, gosto popular e ação social organizada". In: COHN, Gabriel (org.) Comunicação e indústria cultural. São Paulo: Nacional, 1971, p. 230 a 253.

LIPOVETSKY, Gilles. 0 império do efêmero. São Paulo: Companhia das Letras, 1989

MATTELART, Armand e Michèle. História das teorias da comunicação. São Paulo: Loyola, 1999.

McCOMBS, Maxwell. "Influencia de las noticias sobre nuestras imágenes del mundo". In: BRYANT, Jennings e ZILLMANN, Dolf. Los efectos de los medios de comunicación. Investigaciones y teorias. Barcelona: Paidós, 1996.

McCOMBS, Maxwell E. "The evolution of agenda-setting research: twenty-five years in the marketplace of ideas". 
Journal of Communication, 43 (2) Spring 1993.

McCOMBS, Maxwell E. and SHAW, Donald L. "The agendasetting function of mass media". In: Public Opinion Quarterly, Vol. 36, Número 2, Summer 1972, p. 176 a 187

MCLEOD, Jack M., KOSICKI, Gerald M. e McLEOD, Douglas M. "Expansión de los efectos de comunicación política". In: BRYANT, Jennings e ZILLMANN, Dolf. Los efectos de los medios de comunicación. Investigaciones e teorías. Barcelona: Paidós, 1996.

NOELLE-NEUMANN, Elisabeth. La espiral del silencio. Opinión pública: nuestra piel social. Barcelona: Paidós, 1995.

ROGERS, Everett M. "The anatomy of agenda-setting research". In: Journal of Communication, 43 (2), Spring, 1993

SAMPEDRO BLANCO, Víctor Fco. "Efectos de los medios de comunicación sobre la opinión pública. Los paradigmas sobre el poder del público" (texto inédito).

SAMPEDRO BLANCO, Victor. Movimientos sociales: debates sin mordaza. Desobediencia civil servicio militar (1970-1996). Madrid: Centro de Estudios Constitucionales, 1997.

SHAW, Donald L. and McCOMBS, Maxwell E. The emergence of american political issues: The agenda-setting function of the press. Saint Paul, Minnesotta, West Publishing Co.

TRAQUINA, Nelson. "O paradigma do agenda-setting: Redescoberta do poder do jornalismo". In: Revista Comunicação e Linguagens. Lisboa: Cosmos, número 21 e 22, 1995.

WOLF, Mauro. Teorias da comunicação. Lisboa: Presença, 1986 